\section{Gibberellic Acid Shows Promise for Promoting Flower Stem Length in Four Field-grown Cut Flowers}

\author{
Ben A. Bergmann, John M. Dole ${ }^{1}$, and Ingram McCall
}

ADDITIONAL INDEX WORDs. production time, harvest date

SUMMARY. Increasing cut stem length and reducing crop production time are producers' goals for numerous cut flower species. One or both of these aims was met in several field-grown cultivars through foliar application of gibberellic acid $\left(\mathrm{GA}_{3}\right)$, but effectiveness varied by cultivar, application rate, and timing. Of the 13 cultivars tested, stem length was increased in nine cultivars [Toreador Red celosia (Celosia argentea), Camelot White foxglove (Digitalis purpurea), Imperial Giants Pink Perfection larkspur (Larkspur hybrids), Compliment mix lobelia (Lobelia hybrids), Nippon Taka ornamental pepper (Capsicum annuum), Amazon Neon Duo and Bouquet Purple sweet william (Dianthus hybrids), Summer Pastels yarrow (Achillea millefolium), and Benary's Giant Scarlet zinnia (Zinnia elegans)], and time to harvest was decreased in four cultivars [High Tide White ageratum (Ageratum boustonianum), lobelia, ornamental pepper, and zinnia], when $\mathrm{GA}_{3}$ was applied as a foliar spray. Concentrations of 400,800 , and $1600 \mathrm{mg} \cdot \mathrm{L}^{-1} \mathrm{GA}_{3}$ were most effective. Application of $\mathrm{GA}_{3}$ resulted in malformed or smaller flowers or lighter green foliage in foxglove, lobelia, sweet william, and zinnia. In most cases, only one application was tested, and greatest response to $\mathrm{GA}_{3}$ was observed during 3-6 weeks post application. Gibberellic acid did not influence stem length in three cultivars [High Tide White ageratum, Aurora Deep Purple delphinium (Delphinium hybrids), and Column Lilac Lavender stock (Matthiola incana)], and decreased flower stem length in one cultivar (High Tide Blue ageratum). Four cultivars were identified as good candidates for further research given their promising responses to $\mathbf{G A}_{3}$ treatments.

S uccessful cut flower production depends on the ability to produce crops economically in a short, predictable amount of time. Profitability of a cut flower cultivar relies on market price, yield of long, strong, and easy-toharvest stems, manageable insect and disease pressures, short crop cycle, and long postharvest life (Armitage and Laushman, 2003; Bridgen, 1992). Few cultivars have all these characteristics. Common problems include unacceptably short stems, long production times, or lengthy flower-initiation procedures. Growers may be able to alleviate some of these issues by applying gibberellic acid to their crops.

Gibberellic acid can be used to break dormancy, promote stem elongation, and replace photoperiodic requirements (Kende and Zeevaart, 1997; Pharis and King, 1985; Sharma and Kumar, 2005; Wittwer and Bukovac,

Department of Horticultural Science, North Carolina State University, Raleigh, NC 27695

We gratefully acknowledge funding from Valent Biosciences, and support from floriculture research technician Diane Mays, as well as cut flower suppliers and graduate students.

${ }^{1}$ Corresponding author. E-mail: john_dole@ncsu. edu.
1957). Examples of cut flowers that are treated with $\mathrm{GA}_{3}$ during production include lisianthus (Eustoma grandiflorum) to prevent rosetting and shorten production time (Jie et al., 2003; JongWon et al., 2000), calla lily (Zantedeschia albomaculata) to increase the number of flowers and shorten production time (Ball, 1991), and species in which $\mathrm{GA}_{3}$ can be used to break dormancy such as liatris (Liatris spicata), monkshood (Aconitum napellus), and peony (Paeonia suffruticosa) as reported by Wanjao and Waithaka (1983), Lurie et al. (1992), and GuoSheng et al. (2009), respectively. With other species, such as cut poinsettia (Euphorbia pulcherrima), tall stems can be produced without $\mathrm{GA}_{3}$, but using the growth regulator can produce the desired height in a shorter time period
(Hartrath, 1987). Three benefits were achieved by treating perennial aster (Aster ericoides) with $\mathrm{GA}_{3}$ : breaking dormancy, increasing stem length, and reducing production time (Naranja and Balladares, 2008).

Because $\mathrm{GA}_{3}$ effects can vary greatly among different taxa, the objective of these trials was to quantify the effects of $\mathrm{GA}_{3}$ on cut stem production in 13 field-grown, cut flower cultivars: ageratum (two cultivars), celosia, delphinium, foxglove, larkspur, lobelia, ornamental pepper, stock, sweet william, dianthus (two cultivars), yarrow, and zinnia.

\section{Materials and methods}

Experiments with 13 cut flower cultivars were conducted at the North Carolina State University Horticultural Field Laboratory in Raleigh, NC. Separate experiments were conducted in three different years with four, five, and four cultivars used in years 1,2 , and 3 , respectively.

Trial plants were started in a greenhouse from seed early each spring or obtained as plugs from commercial suppliers $\approx 2$ weeks before field planting. Standard greenhouse management included growing plants in bedding plant flats with $2.25 \times 1.50 \times 2.13$ inch individual cells containing soilless substrate (Fafard 4P; Conrad Fafard, Agawam, MA), fertilizing at each overhead irrigation with $150 \mathrm{mg} \cdot \mathrm{L}^{-1}$ nitrogen $(\mathrm{N})$ from $20 \mathrm{~N}-4.4 \mathrm{P}-16.6 \mathrm{~K}$ liquid fertilizer [20-10-20 (Everris, Dublin, $\mathrm{OH})$ ], and setting temperatures to $24 / 18^{\circ} \mathrm{C}$ (day/night). Trial plants were transplanted to the field at $12 \times 12$-inch spacing before imposition of $\mathrm{GA}_{3}$ treatments. Raised beds had been amended with ammonium nitrate applied at $100 \mathrm{lb} /$ acre $\mathrm{N}$ before transplanting, and drip irrigation was used as necessary during the experiments.

Experiments were established as randomized complete block designs with four beds serving as the four blocks and each cultivar $\times$ treatment combination serving as an experimental

\begin{tabular}{llll}
\hline $\begin{array}{l}\text { Units } \\
\begin{array}{l}\text { To convert U.S. to SI, } \\
\text { multiply by }\end{array}\end{array}$ & U.S. unit & SI unit & $\begin{array}{l}\text { To convert SI to U.S., } \\
\text { multiply by }\end{array}$ \\
\hline 2.54 & inch $(\mathrm{es})$ & $\mathrm{cm}$ & 0.3937 \\
1.1209 & $\mathrm{lb} / \mathrm{acre}$ & $\mathrm{kg} \cdot h \mathrm{ha}^{-1}$ & 0.8922 \\
1 & $\mathrm{ppm}$ & $\mathrm{mg} \cdot \mathrm{L}^{-1}$ & 1 \\
$\left({ }^{\circ} \mathrm{F}-32\right) \div 1.8$ & ${ }^{\circ} \mathrm{F}$ & ${ }^{\circ} \mathrm{C}$ & $\left({ }^{\circ} \mathrm{C} \times 1.8\right)+32$
\end{tabular}


unit within each block. Individual plants per treatment in each block served as subsamples - the number of which was consistent within each cultivar but differed among cultivars. Data were analyzed using analysis of variance (SAS version 9.2; SAS Institute, Cary, NC), and means were separated using least significant difference test at $P \leq 0.05$.

Year 1. 'Aurora Deep Purple' delphinium, 'Imperial Giants Pink Perfection' larkspur, 'Column Lilac Lavender' stock, and 'Amazon Neon Duo' sweet william seeds were sown on 9 Jan. Plants were transplanted to the field on 3 Mar. Plants were sprayed to point of runoff from leaves and stems on 17 Mar. with $0,50,100,200$, or $400 \mathrm{mg} \cdot \mathrm{L}^{-1} \mathrm{GA}_{3}$ (ProGibb; Valent BioSciences, Walnut Creek, CA). Two weeks later, a second application of equal concentration was applied to half of the plants that had received 50, 100, or $200 \mathrm{mg} \cdot \mathrm{L}^{-1} \mathrm{GA}_{3}$. Subsample number for each treatment by block combination was 16, 8, and 6 for larkspur and sweet william, stock, and delphinium, respectively.

Delphinium, larkspur, and stock stems were harvested when $1 / 4$ to $1 / 3$ of the flowers on the inflorescence were fully open. Sweet william stems were harvested when three to five florets were open on the inflorescence. Recorded data included date of harvest and stem length at harvest.

Year 2. 'Toreador Red' celosia, 'Camelot White' foxglove, and 'Benary's Giant Scarlet' zinnia seeds were sown on 30 Jan., and plugs of 'Bouquet Purple' sweet william and 'Summer Pastels' yarrow were received from a commercial grower on 1 May. Plugs and seedlings were transplanted to the field on 29 Mar. (foxglove), 14 May (sweet william and zinnia), or 19 May (celosia and yarrow). Plants were sprayed to point of runoff from leaves and stems on 30 June with $0,200,400,800$, or $1600 \mathrm{mg} \cdot \mathrm{L}^{-1} \mathrm{GA}_{3}$ (ProGibb). Plants were well established and a few (sweet william and yarrow) or all (celosia, foxglove, and zinnia) had just begun to produce flower stalks when treatments were imposed. Subsample number for each treatment by block combination was $16,12,8$, and 4 for celosia, zinnia, sweet william and yarrow, and foxglove, respectively.

Flowers were harvested when one to three florets (foxglove), three to four florets (sweet william), or at least half of the florets (yarrow) on the inflorescence was fully open. Celosia flowers were harvested when the heads reached full size and florets at the base of the head were fully open. Zinnia flowers were harvested when the petals on the outer rows had unfurled. Flowers were cut over three (celosia and zinnia) or five (foxglove, sweet william, and yarrow) 10-d harvest periods. Recorded data were the number of flowers per harvest period, flower stem length, and zinnia flower diameters.

YeAr 3. 'High Tide Blue' and 'High Tide White' ageratum and 'Nippon Taka' ornamental pepper seeds were sown and plugs of 'Compliment' mix lobelia were received from a commercial grower on 1 Apr. Plants were transplanted to the field on 13 Apr. (lobelia), 25 Apr. (ageratum), or 4 May (ornamental pepper). In addition to the pretransplant nitrogen incorporated into the raised beds as in previous years, beds were fertilized with $200 \mathrm{mg} \cdot \mathrm{L}^{-1} \mathrm{~N}$ from $20 \mathrm{~N}-4.4 \mathrm{P}-$ $16.6 \mathrm{~K}$ through drip irrigation on 12 June and 12 July. Plants were sprayed to point of runoff from leaves and stems on 19 June with $0,200,400$, 800 , or $1600 \mathrm{mg} \cdot \mathrm{L}^{-1} \mathrm{GA}_{3}$ (ProGibb). Plants were well established and had begun producing flowers (ageratum and ornamental pepper) or flower stalks (lobelia) at the time treatments were imposed. Subsample number for each treatment by block combination was 12,6 , and 4 for ornamental pepper, lobelia, and ageratum, respectively.

Ageratum flowers were harvested when the center florets were open and the lateral florets were well colored. Ornamental pepper was harvested when most of the fruit were well colored. Lobelia flowers were harvested when three to four florets on the inflorescence were fully open. Recorded data included date of harvest and stem length at harvest.

\section{Results}

YEAR 1. Gibberellic acid increased flower stem length in larkspur and sweet william but not in delphinium and stock. Compared with water-treated controls, stem length of 'Imperial Giants Pink Perfection' larkspur was increased by 6.6 or $17.3 \mathrm{~cm}$ with one application of 200 or 400 $\mathrm{mg} \cdot \mathrm{L}^{-1} \mathrm{GA}_{3}$, respectively (Table $\mathrm{l}$ ). Flower stem length of 'Amazon Neon Duo' sweet william was increased by $7.2 \mathrm{~cm}$ over the control with two applications of $200 \mathrm{mg} \cdot \mathrm{L}^{-1}$ $\mathrm{GA}_{3}$ (Table 1).

Gibberellic acid applications did not affect the number of flowers harvested, the average number of days to flower harvest, or flower appearance of the four first-year cultivars (data not shown). We observed that foliage of sweet william plants was lighter green for 7-10 d after treatment.

YeAR 2. Flower stem length caused by $\mathrm{GA}_{3}$ was greater in the five cultivars tested (Table 2). Considering all flowers cut overall harvest periods, average stem length increase was greatest when $\mathrm{GA}_{3}$ was applied at 800 or $1600 \mathrm{mg} \cdot \mathrm{L}^{-1}$ in celosia $(3.1-$ $4.1 \mathrm{~cm}$ increase), at $800 \mathrm{mg} \cdot \mathrm{L}^{-1}$ in foxglove $(8.6 \mathrm{~cm}$ increase), and at 400 to $1600 \mathrm{mg} \cdot \mathrm{L}^{-1}$ in 'Bouquet Purple' sweet william $(2.3-4.5 \mathrm{~cm}$ increase), yarrow (3.0-4.5 cm increase), and zinnia (1.5-2.3 cm increase). The greatest disparity in flower stem length between the water control and $\mathrm{GA}_{3}$ treated plants was much larger during certain harvest periods. For example, sweet william treated with $1600 \mathrm{mg} \cdot \mathrm{L}^{-1}$ $\mathrm{GA}_{3}$ produced flower stem lengths that were $9.3 \mathrm{~cm}$ longer than those from control plants during the second harvest period (Fig. 1). Yarrow treated with $400 \mathrm{mg} \cdot \mathrm{L}^{-1} \mathrm{GA}_{3}$ produced flower stem lengths that were $5.4 \mathrm{~cm}$ longer than those from control plants during the first harvest period (Fig. 1).

Treatment with $800 \mathrm{mg} \cdot \mathrm{L}^{-1} \mathrm{GA}_{3}$ resulted in the longest foxglove flower stems, the only cultivar for which stems produced on plants treated with the highest $\mathrm{GA}_{3}$ concentration were significantly shorter than for the next lower concentration (Table 2). Likewise, foxglove was the only cultivar in which flower malformations were common, occurring after all $\mathrm{GA}_{3}$ treatments and becoming more prevalent as concentration increased. An insufficient number of cut stems were produced to draw conclusions beyond the basic stem length observations.

Gibberellic acid treatments increased average flower stem length at harvest beyond more than $30 \mathrm{~d}$ after application for celosia, sweet william, yarrow, and zinnia (Fig. 1). Longer flower stems from $\mathrm{GA}_{3}$-treated plants were the norm during the last harvest period for celosia and zinnia, which had three 10-d harvest periods, but the influence of $\mathrm{GA}_{3}$ appeared to have waned by the last harvest period in 
Table 1. Effect of gibberellic acid $\left(\mathrm{GA}_{3}\right)$ on flower stem length of field-grown 'Imperial Giants Pink Perfection' larkspur and 'Amazon Neon Duo' sweet william. Plants were sprayed with $\mathrm{GA}_{3} 2$ weeks after transplant to the field and again 2 weeks later in all cases but the $400 \mathrm{mg} \cdot \mathrm{L}^{-1}$ treatment, which was not repeated. Means are an average of 16-33 stems.

\begin{tabular}{rccc}
\hline & & \multicolumn{2}{c}{ Stem length $(\mathrm{cm})^{\mathrm{z}}$} \\
\cline { 3 - 4 } $\mathbf{G A}_{\mathbf{3}}\left(\mathbf{m g} \cdot \mathbf{L}^{-\mathbf{1}}\right)^{\mathbf{z}}$ & Applications (no.) & Larkspur & Sweet william \\
\hline 0 & 1 & $52.3 \mathrm{c}^{\mathrm{y}}$ & $47.2 \mathrm{c}$ \\
50 & 1 & $50.5 \mathrm{c}$ & $48.8 \mathrm{bc}$ \\
50 & 2 & $53.8 \mathrm{bc}$ & $49.3 \mathrm{~b}$ \\
100 & 1 & $54.6 \mathrm{bc}$ & $49.5 \mathrm{~b}$ \\
100 & 2 & $50.8 \mathrm{c}$ & $49.5 \mathrm{~b}$ \\
200 & 1 & $58.9 \mathrm{~b}$ & $48.8 \mathrm{bc}$ \\
200 & 2 & $55.6 \mathrm{bc}$ & $54.4 \mathrm{a}$ \\
400 & 1 & $69.6 \mathrm{a}$ & $48.3 \mathrm{bc}$ \\
& ANOVA significance & 0.0001 & 0.0001 \\
\hline
\end{tabular}

ANOVA $=$ analysis of variance.

${ }^{\mathrm{z}} 1 \mathrm{mg} \cdot \mathrm{L}^{-1}=1 \mathrm{ppm}, \mathrm{l} \mathrm{cm}=0.3937$ inch

yAverages within a column followed by the same letter are not significantly different at $P \leq 0.05$ using least significant difference test.

Table 2. Effect of gibberellic acid $\left(\mathrm{GA}_{3}\right)$ on flower stem length of field-grown 'Toreador Red' celosia, 'Camelot White' foxglove, 'Bouquet Purple' sweet william, 'Summer Pastels' yarrow, and 'Benary's Giant Scarlet' zinnia. Plants were sprayed one time with $\mathrm{GA}_{3} 42 \mathrm{~d}$ (celosia and yarrow), $50 \mathrm{~d}$ (sweet william and zinnia), or $62 \mathrm{~d}$ (foxglove) after transplant to the field. Means are an average of 218-267 stems (celosia), 24-45 stems (foxglove), 318-391 stems (sweet william), 74-133 stems (yarrow), or 262-319 stems (zinnia).

\begin{tabular}{cccccc}
\hline & \multicolumn{5}{c}{ Stem length $(\mathrm{cm})^{\mathrm{z}}$} \\
\cline { 2 - 6 } $\mathbf{G A}_{\mathbf{3}}\left(\mathbf{m g} \cdot \mathbf{L}^{-\mathbf{1}}\right)^{\mathbf{z}}$ & Celosia & Foxglove & Sweet william & Yarrow & Zinnia \\
\hline 0 & $28.7 \mathrm{~d}^{\mathrm{y}}$ & $38.6 \mathrm{c}$ & $24.1 \mathrm{c}$ & $35.1 \mathrm{c}$ & $46.5 \mathrm{c}$ \\
200 & $30.0 \mathrm{c}$ & $42.7 \mathrm{~b}$ & $26.4 \mathrm{~b}$ & $36.3 \mathrm{bc}$ & $47.0 \mathrm{bc}$ \\
400 & $31.0 \mathrm{bc}$ & $40.9 \mathrm{bc}$ & $28.4 \mathrm{a}$ & $38.4 \mathrm{a}$ & $48.0 \mathrm{ab}$ \\
800 & $31.8 \mathrm{ab}$ & $47.2 \mathrm{a}$ & $27.9 \mathrm{a}$ & $39.6 \mathrm{a}$ & $48.8 \mathrm{a}$ \\
1,600 & $32.8 \mathrm{a}$ & $43.2 \mathrm{~b}$ & $27.9 \mathrm{a}$ & $38.1 \mathrm{ab}$ & $48.5 \mathrm{ab}$ \\
ANOVA significance & 0.0001 & 0.0001 & 0.0001 & 0.0003 & 0.0220 \\
\hline
\end{tabular}

ANOVA = analysis of variance.

${ }^{\mathrm{z}} \mathrm{l} \mathrm{mg} \cdot \mathrm{L}^{-1}=1 \mathrm{ppm}, \mathrm{l} \mathrm{cm}=0.3937$ inch

y Averages within a column followed by the same letter are not significantly different at $P \leq 0.05$ using least significant difference test.

sweet william and yarrow, which had five 10-d harvest periods (Fig. 1).

Application of $\mathrm{GA}_{3}$ in zinnias had two statistically significant effects apart from flower stem length. All $\mathrm{GA}_{3}$ treatments resulted in reduced flower diameter (Table 3), though number and appearance, apart from diameter, of zinnia flowers was unaffected by $\mathrm{GA}_{3}$ treatments. A slightly reduced time to harvest was observed at the higher $\mathrm{GA}_{3}$ concentrations (Table 3).

Gibberellic acid treatments did not influence number of stems produced or time to harvest in celosia, sweet william, or yarrow (data not shown).

YEAR 3. Influence of $\mathrm{GA}_{3}$ treatments on flower/fruit stem length ranged from reduced length to no effect to increased length. Except for the highest concentration, the effect of $\mathrm{GA}_{3}$ treatments on 'High Tide Blue' ageratum was to suppress flower stem elongation as compared with control plants (Table 4). Flower stem length in 'High Tide White' ageratum did not differ among treatments (data not shown). Lobelia flower stems were $9.4 \mathrm{~cm}$ longer than stems from control plants when treated with $800 \mathrm{mg} \cdot \mathrm{L}^{-1} \mathrm{GA}_{3}$, and stem lengths were greatest in ornamental pepper when treated with 400 to 1600 $\mathrm{mg} \cdot \mathrm{L}^{-1} \mathrm{GA}_{3}$ (Table 4).

We observed different responses to $\mathrm{GA}_{3}$ treatments among 'High Tide Blue' and 'High Tide White' ageratum, 'Nippon Taka' ornamental pepper, and 'Compliment' mix lobelia in terms of time to harvest. Lobelia exhibited a trend for higher concentrations of $\mathrm{GA}_{3}$ to reduce the number of days to harvest, with $1600 \mathrm{mg} \cdot \mathrm{L}^{-1} \mathrm{GA}_{3}$ shortening time to harvest by $9 \mathrm{~d}$ compared with control plants (Table 4). The lower concentrations of $\mathrm{GA}_{3}$ significantly influenced time to harvest by shortening the time by as much as $9 \mathrm{~d}$ in 'High Tide White' ageratum and $3 \mathrm{~d}$ in ornamental pepper when treated with 800 and $200 \mathrm{mg} \cdot \mathrm{L}^{-1} \mathrm{GA}_{3}$, respectively. Of the $\mathrm{GA}_{3}$ treatments, only $800 \mathrm{mg} \cdot \mathrm{L}^{-1}$ differed from control plants in 'High Tide Blue' ageratum, with the $\mathrm{GA}_{3}$-treated plants taking $2 \mathrm{~d}$ longer than controls to yield harvestable flowers (Table 4).

Gibberellic acid did not influence the number of flower/fruit stems in any cultivar (data not shown). Ageratum cultivars and ornamental pepper appeared consistently normal in flower/ fruit appearance, but lobelia exhibited occasional flower abnormalities when plants were treated with $1600 \mathrm{mg} \cdot \mathrm{L}^{-1}$ $\mathrm{GA}_{3}$.

\section{Discussion}

Applications of $\mathrm{GA}_{3}$ were used on 13 field-grown cut flower cultivars with the aim of increasing flower stem length and/or shortening time to harvest. To show promise for commercial implementation, the benefit(s) of $\mathrm{GA}_{3}$ treatments would have to be great enough to have practical importance without significant deleterious effects. With this thought in mind, our work allowed us to divide the tested cultivars into groups according to the likelihood that $\mathrm{GA}_{3}$ treatment would have practical benefit in developing new field-grown, cut flower protocols (Table 5). Additional research is required to refine treatments and demonstrate that $\mathrm{GA}_{3}$ treatments are an economically viable option for improving field-grown, cut flower production in the four cultivars for which we found that $\mathrm{GA}_{3}$ application holds promise: Bouquet Purple sweet william, Imperial Giants Pink Perfection larkspur, Summer Pastels yarrow, and Toreador Red celosia.

We found that $\mathrm{GA}_{3}$ increased flower stem length in nine of the 13 cultivars tested, with $400 \mathrm{mg} \cdot \mathrm{L}^{-1} \mathrm{GA}_{3}$ or higher resulting in the longest stems for most cultivars. One application was tested in most cases, and the most pronounced influence of $\mathrm{GA}_{3}$ was typically observed 3-6 weeks after application. One cultivar (High 

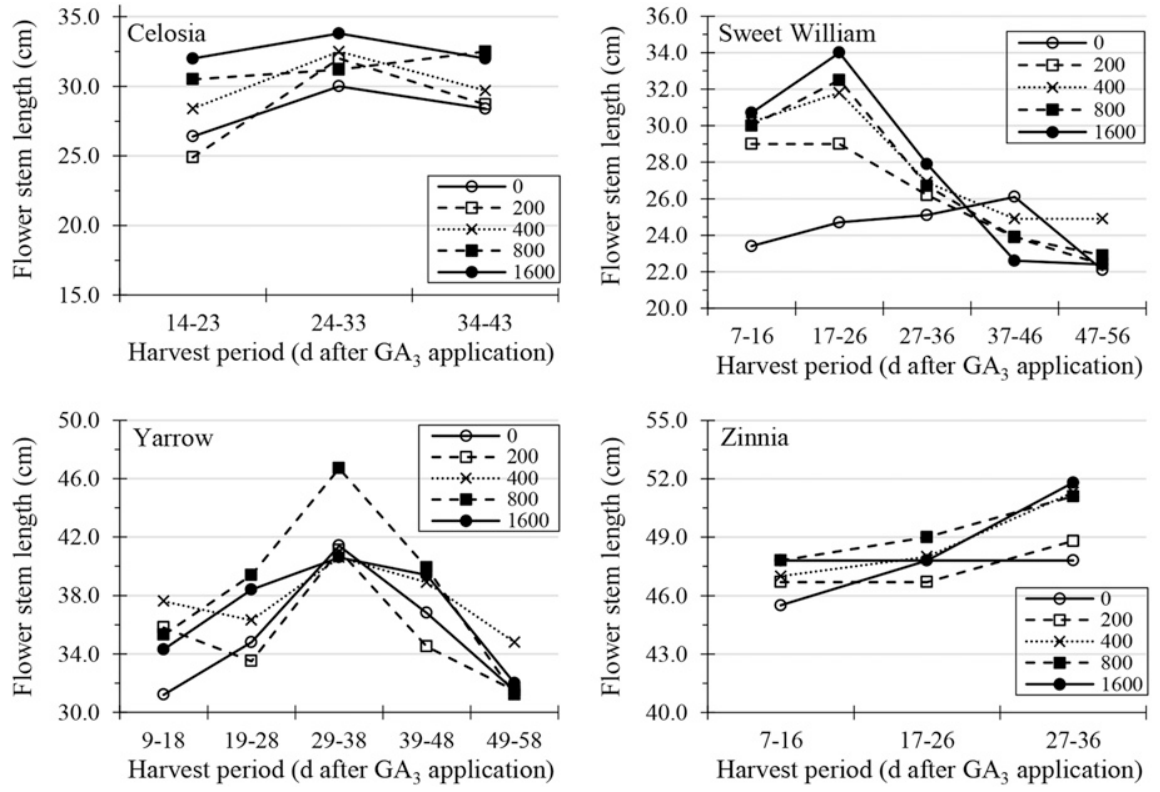

Fig. 1. Effect of gibberellic acid $\left(\mathrm{GA}_{3}\right)$ and number of days between $\mathrm{GA}_{3}$ application and flower harvests on flower stem length of field-grown 'Toreador Red' celosia, 'Camelot White' foxglove, 'Bouquet Purple' sweet william, 'Summer Pastels' yarrow, and 'Benary's Giant Scarlet' zinnia. Plants were sprayed one time with $\mathrm{GA}_{3} 42 \mathrm{~d}$ (celosia and yarrow), $50 \mathrm{~d}$ (sweet william and zinnia), or $62 \mathrm{~d}$ (foxglove) after transplant to the field. Concentrations in legend are in $\mathrm{mg} \cdot \mathrm{L}^{-1}$. Stem lengths were recorded during three (celosia and zinnia) or five (sweet william and yarrow) 10 -d harvest periods. Statistical separation of averages within cultivar and across harvest period are shown in Table $2 ; 1 \mathrm{mg} \cdot \mathrm{L}^{-1}=1 \mathrm{ppm}$, $1 \mathrm{~cm}=0.3937$ inch .

Table 3. Effect of gibberellic acid $\left(\mathrm{GA}_{3}\right)$ on 'Benary's Giant Scarlet' zinnia flower diameter and days to flower harvest. Averages are calculated using 40 stems (diameter) and 262-319 stems (harvest).

\begin{tabular}{ccc}
\hline $\mathrm{GA}_{\mathbf{3}}\left(\mathbf{m g} \cdot \mathrm{L}^{-\mathbf{1}}\right)^{\mathrm{z}}$ & Flower diam $(\mathbf{c m})^{\mathrm{z}}$ & Time to harvest $(\mathrm{d})$ \\
\hline 0 & $5.8 \mathrm{a}^{\mathrm{y}}$ & $90 \mathrm{a}$ \\
200 & $4.8 \mathrm{~b}$ & $89 \mathrm{ab}$ \\
400 & $4.8 \mathrm{~b}$ & $88 \mathrm{~b}$ \\
800 & $4.3 \mathrm{~b}$ & $89 \mathrm{ab}$ \\
1,600 & $4.3 \mathrm{~b}$ & $87 \mathrm{~b}$ \\
ANOVA significance & 0.0001 & 0.0255 \\
\hline
\end{tabular}

ANOVA $=$ analysis of variance.

${ }^{2} 1 \mathrm{mg} \cdot \mathrm{L}^{-1}=1 \mathrm{ppm}, 1 \mathrm{~cm}=0.3937$ inch.

yerages followed by the same letter are not significantly different at $P \leq 0.05$ using least significant difference test.

Tide Blue ageratum) had shorter flower stems in some of the $\mathrm{GA}_{3}$ treatments as compared with controls, and three cultivars appeared to be insensitive to foliar applications of $\mathrm{GA}_{3}$, similar to findings in Brilliant Barbara stock (Grzesik, 1995). Because the $\mathrm{GA}_{3}$ concentrations we used were based primarily on published literature for greenhouse-grown crops, concentrations and number of applications used in these studies may have been too low to affect growth of the cultivars that appeared $\mathrm{GA}_{3}$ insensitive, especially as field-grown plants may have lower
$\mathrm{GA}_{3}$ absorption given their thicker cuticle compared with greenhousegrown plants (Bleckmann et al., 1980; Sandoval et al., 1994; Stover and Greene, 2005; Templeton and Hurtt, 1972).

As has been shown in gladiolus (Gladiolus) by Dua et al. (1984) and chrysanthemum (Chrysanthemum morifolium) by Gupta and Datta (2000), we observed shorter harvest times in four of the tested cultivars. Our work showed a reduced time to harvest in response to $\mathrm{GA}_{3}$ application ranging from $3 \mathrm{~d}$ in ornamental pepper and zinnia to $9 \mathrm{~d}$ in 'High Tide White' ageratum and lobelia. Our finding with zinnia contrasts with earlier research showing that application of $200 \mathrm{mg} \cdot \mathrm{L}^{-1}$ $\mathrm{GA}_{3}$ delayed bud initiation by $1.6 \mathrm{~d}$ (Sharma et al., 2008). None of the four cultivars exhibiting reduced time to harvest were among the cultivars we believe showed promising benefit from $\mathrm{GA}_{3}$ treatment, but the limited benefit of $\mathrm{GA}_{3}$ in three of them may warrant further investigation (Table 5 ).

The negative effects of $\mathrm{GA}_{3}$ applications that we observed in some cultivars, such as reduced flower diameter in zinnia, lighter green foliage in sweet william, and flower malformations in foxglove and lobelia, were not surprising given previous research with these and other cut flowers. Keever (1999) documented that flower malformations and lighter green foliage occurred along with longer flower stems in foxglove treated with $\mathrm{GA}_{3}$. Temporarily lighter green foliage following $\mathrm{GA}_{3}$ applications was noted by Marth et al. (1956) in many of the dozens of plant taxa tested in their seminal work. Other negative side effects on horticultural production characteristics caused by $\mathrm{GA}_{3}$ include reduced flower diameter and malformation in cosmos (Cosmos bipinnatus), later and fewer florets in gladiolus, flower deformities in billy buttons (Craspedia globosa), decreased fruit production in chili pepper (Capsicum baccatum), and reduced spadix width and flower abnormalities in calla lily as reported by Molder and Owens (1974), Dua et al. (1984), Annis et al. (1992), Tofanelli et al. (2003), and Choi et al. (2005), respectively.

For the 13 cultivars tested in this work, increased flower stem length was necessary but not sufficient for us to consider a cultivar as having an overall benefit from $\mathrm{GA}_{3}$ treatment. Of the nine cultivars that responded to $\mathrm{GA}_{3}$ treatments by producing stems that were statistically significantly longer, five had stem length increases that were insufficiently great and/or had the greater stem length accompanied by other negative response(s). For example, zinnia produced flower stems up to $4.0 \mathrm{~cm}$ longer than control plants, but the $8 \%$ increase in stem length was accompanied by an only slightly reduced harvest time $(3 \%)$ and a very large reduction in flower diameter $(26 \%)$. Increasing flower stem length by up to $8.6 \mathrm{~cm}$ in foxglove was 
Table 4. Effect of gibberellic acid $\left(\mathrm{GA}_{3}\right)$ on flower stem length and time to harvest from transplanting in 'High Tide Blue' ageratum, 'High Tide White' ageratum, 'Compliment' mix lobelia, and 'Nippon Taka' ornamental pepper. Plants were sprayed one time with $0,200,400,800$, or $1600 \mathrm{mg} \cdot \mathrm{L}^{-1} \mathrm{GA}_{3}$. Averages are from $197-289 \mathrm{stems}$ (' $\mathrm{High}$ Tide Blue' ageratum), 21-85 stems ('High Tide White' ageratum), 21-97 stems (lobelia), or 201-231 stems (ornamental pepper).

\begin{tabular}{|c|c|c|c|c|c|c|c|}
\hline \multirow[b]{2}{*}{$\mathrm{GA}_{3}\left(\mathrm{mg} \cdot \mathrm{L}^{-1}\right)^{\mathrm{z}}$} & \multicolumn{3}{|c|}{ Stem length $(\mathrm{cm})^{\mathrm{z}}$} & \multicolumn{4}{|c|}{ Time to harvest (d) } \\
\hline & $\begin{array}{l}\text { 'High Tide Blue' } \\
\text { ageratum }\end{array}$ & $\begin{array}{c}\text { Ornamental } \\
\text { pepper }\end{array}$ & Lobelia & $\begin{array}{c}\text { 'High Tide Blue' } \\
\text { ageratum }\end{array}$ & $\begin{array}{c}\text { 'High Tide White' } \\
\text { ageratum }\end{array}$ & $\begin{array}{c}\text { Ornamental } \\
\text { pepper }\end{array}$ & Lobelia \\
\hline 200 & $19.6 \mathrm{c}$ & $34.0 \mathrm{~b}$ & $68.8 \mathrm{bc}$ & $104 \mathrm{ab}$ & $103 \mathrm{~b}$ & $146 \mathrm{~b}$ & $108 \mathrm{a}$ \\
\hline 400 & $23.4 \mathrm{~b}$ & $34.8 \mathrm{ab}$ & $67.8 \mathrm{c}$ & $103 \mathrm{bc}$ & $104 \mathrm{~b}$ & $147 \mathrm{~b}$ & $105 \mathrm{ab}$ \\
\hline 800 & $23.4 \mathrm{~b}$ & $34.5 \mathrm{ab}$ & $77.5 \mathrm{a}$ & $105 \mathrm{a}$ & $101 \mathrm{~b}$ & $149 \mathrm{a}$ & $101 \mathrm{bc}$ \\
\hline
\end{tabular}

ANOVA $=$ analysis of variance.

${ }^{\mathrm{z}} 1 \mathrm{mg} \cdot \mathrm{L}^{-1}=1 \mathrm{ppm}, 1 \mathrm{~cm}=0.3937$ inch

y Averages within a column followed by the same letter are not significantly different at $P \leq 0.05$ using least significant difference test.

Table 5. Thirteen cultivars grouped according to whether gibberellic acid $\left(\mathrm{GA}_{3}\right)$ treatments were found to be neutral/ detrimental, of limited benefit, or potentially beneficial in the production of field-grown cut flowers.

Cultivars in which $\mathrm{GA}_{3}$ treatments were neutral or detrimental

Aurora Deep Blue delphinium

Benary's Giant Scarlet zinnia

Camelot White foxglove

Column Lilac Lavender stock

High Tide Blue ageratum
Observations of $\mathrm{GA}_{3}$ treated plants compared with control plants ${ }^{\mathrm{z}}$

Same flower stem length, flower number, timing of flowering, and flower appearance Increased flower stem length by up to $4.0 \mathrm{~cm}(8 \%)$, reduced time to harvest by up to $3 \mathrm{~d}(3 \%)$, reduced flower diameter by up to $1.5 \mathrm{~cm}(26 \%)$

Increased flower stem length by up to $8.6 \mathrm{~cm}(22 \%)$, high flower malformation frequency Same flower stem length, flower number, timing of flowering, and flower appearance

Reduced flower stem length by up to $5.5 \mathrm{~cm}(22 \%)$, increased time to harvest by up to $2 \mathrm{~d}(2 \%)$

Cultivars in which $\mathrm{GA}_{3}$ treatments were of limited benefit

Observations of $\mathrm{GA}_{3}$ treated plants compared with control plants

Increased flower stem length by up to $7.2 \mathrm{~cm}(15 \%)$, same flower number, timing of flowering, and flower appearance

Compliment mix lobelia

Increased flower stem length by up to $9.4 \mathrm{~cm}(14 \%)$, reduced time to harvest by up to $9 \mathrm{~d}(9 \%)$, flower malformation seen on occasion at highest $\mathrm{GA}_{3}$ concentration

High Tide White ageratum

Nippon Taka ornamental pepper

Same flower stem length, reduced time to harvest by up to $9 \mathrm{~d}(9 \%)$

Increased fruit stem length by up to $3.3 \mathrm{~cm}(10 \%)$, reduced time to harvest by up to $3 \mathrm{~d}(2 \%)$

Cultivars in which $\mathrm{GA}_{3}$ treatments were beneficial

\section{Observations of $\mathrm{GA}_{3}$ treated plants compared} with control plants

Bouquet Purple sweet william

Imperial Giants Pink Perfection larkspur

Summer Pastels yarrow

Toreador Red celosia
Increased flower stem length by up to $9.3 \mathrm{~cm}(38 \%)$, same flower number, timing of flowering, and flower appearance

Increased flower stem length by up to $17.3 \mathrm{~cm} \mathrm{(33 \% ),} \mathrm{same} \mathrm{flower} \mathrm{number,}$ timing of flowering, and flower appearance

Increased flower stem length by up to $6.4 \mathrm{~cm}(21 \%)$, same flower number, timing of flowering, and flower appearance

Increased flower stem length by up to $5.6 \mathrm{~cm}(21 \%)$, same flower number, timing of flowering, and flower appearance

${ }^{\mathrm{z}} 1 \mathrm{~cm}=0.3937$ inch.

accompanied by an unacceptably high frequency of flower malformations. All four of the cultivars that showed clear benefit from $\mathrm{GA}_{3}$ treatment did so by having a greatly increased flower stem length while having unchanged flower number, timing of flowering, and flower appearance (Table 5 ).

\section{Literature cited}

Annis, D.C., T.W. Starman, and P.T. Gibson. 1992. Photoperiod and gibberellic acid modify growth and flowering of Craspedia globosa. HortScience 27:1082-1084.

Armitage, A.M. and J.M. Laushman. 2003. Specialty cut flowers. 2nd ed. Timber Press, Portland, OR.
Ball, V. 1991. Ball RedBook. 15th ed. Ball Publishing, West Chicago, IL.

Bleckmann, C.A., H.M. Hull, and R.W. Hoshaw. 1980. Cuticular ultrastructure of Prosopis velutina and Acacia greggii leaflets. Bot. Gaz. 141:1-8.

Bridgen, M. 1992. Extend your production with late season cut flowers. GrowerTalks 56(1):39-45. 
Choi, S.R., H.C. Lim, M.S. Ahn, J. Ryu, D.C. Choi, M.J. Kim, and J.S. Eun. 2005. Growth and flowering responses to $\mathrm{GA}_{3}$ concentration in colored calla lily 'Black Magic'. Korean J. Hort. Sci. Technol. 23:423-429.

Dua, I.S., O.P. Sehgai, and K.S. Chark. 1984. Gibberellic acid induced earliness and increased production in Gladiolus. Gartenbauwissenschaf 49:91-94.

Grzesik, M. 1995. Effect of growth regulators on plant growth and seed yield of Matthiola incana, 'Brilliant Barbara'. Seed Sci. Technol. 23:801-806.

GuoSheng, Z., G. ShuPeng, and G. WeiLing. 2009. Changes of endogenous hormones during dormancy release by chilling in tree peony. Scientia Silvae Sinicae 45:48-52.

Gupta, V.N. and S.K. Datta. 2000. Influence of gibberellic acid $\left(\mathrm{GA}_{3}\right)$ on growth and flowering in chrysanthemum (Chrysanthemum morifolium, Ramat) cv. Jayanti. Indian J. Plant. Physiol. 6:420422.

Hartrath, H. 1987. Small Euphorbia standards. Deutscher Gartenbau 41:2960-2961.

Jie, L., H. Ohno, and K. Ohkawa. 2003. Effect of uniconazole and gibberellic acid on the bolting and flowering of easybolting Eustoma cultivars. Environ. Control Biol. 41:51-55.

JongWon, L., K. TaeJoung, K. JuHyoung, L. HeeDoo, K. SiDong, Y. Tae, and P. KeeYoeup. 2000. Effects of plant growth regulators on the growth and cut flower quality of Eustoma grandiflorum cv. Platina Violet. Hort. Environ. Biotechnol. 41:419422 .

Keever, G.J. 1999. Response of 'Foxy' foxglove to $\mathrm{GA}_{3}$ and cold treatment. J. Environ. Hort. 17:35-38.

Kende, H. and J.A.D. Zeevaart. 1997. The five "classical" plant hormones. Plant Cell 9:1197-1210.

Lurie, G., A. Borochov, and A.A. Watad. 1992. Aconitum: Effect of tuber size, day length, and $\mathrm{GA}_{3}$ on growth, flowering, and tuber production. Acta Hort. 325: 113-117.

Marth, P.C., W.V. Audia, and J.W. Mitchell. 1956. Effects of gibberellic acid on growth and development of plants of various genera and species. Bot. Gaz. $118(2): 106-111$.

Molder, M. and J.N. Owens. 1974. The effects of gibberellin $\mathrm{A}_{3}$, photoperiod, and age on vegetative growth and flowering in Cosmos bipinnatus var. Sensation. Can. J. Bot. 52:1249-1258.

Naranja, L.R. and M.C.E. Balladares. 2008. Flowering induction of Aster ericoides (L.) using gibberellic acid. Philipp. Agr. Sci. 91:338-342.

Pharis, R.P. and R.W. King. 1985. Gibberellins and reproductive development in seed plants. Annu. Rev. Plant Physiol. 36:517-568.
Sandoval, J.A., L.E. Müller, and F. Weberling. 1994. Foliar morphology and anatomy of Musa cv. Grande Naine (AAA) plants grown in vitro and during hardening as compared to field-grown plants. Fruits 49:37-46.

Sharma, L. and A. Kumar. 2005. Effect of $\mathrm{GA}_{3}$ on growth and flowering of Ageratum conyzoides. J. Phytol. Res. 18:91-94.

Sharma, V., V. Kumar, and A.K. Tyagi. 2008. Growth and flowering of zinnia as influenced by growth regulators. Plant Archives 8:381-382.

Stover, E.W. and D.W. Greene. 2005. Environmental effects on the performance of foliar applied plant growth regulators: A review focusing on tree fruits. HortTechnology 15:214-221.

Templeton, A.R. and W. Hurtt. 1972. Effect of pre-treatment environment on herbicidal response and morphological variation of three species. Proc. Northeastern Weed Sci. Soc. 26:277-283.

Tofanelli, M.B.D., J.E. Amaya-Robles, J.D. Rodrigues, and E.O. Ono. 2003. Gibberellic acid on pepper parthenocarpic fruits production. Hort. Bras. 21:116-118.

Wanjao, L.W. and K. Waithaka. 1983. The effect of $\mathrm{GA}_{3}$ application on growth and flowering of Liatris. Scientia Hort. 19:343-348.

Wittwer, S.H. and M.J. Bukovac. 1957. Gibberellin effects on temperature and photoperiodic requirements for flowering of some plants. Science 126:30-31. 